Rev. Int. Contam. Ambie. 35 (2) 295-305, 2019

DOI: 10.20937/RICA.2019.35.02.03

\title{
HERBICIDE GENOTOXICITY REVEALED WITH THE SOMATIC WING SPOT ASSAY OF Drosophila melanogaster
}

(Detección de la genotoxicidad inducida por herbicidas en el ensayo somático de las alas de Drosophila melanogaster)

\author{
América Nitxin CASTAÑEDA-SORTIBRÁN, Claudia FLORES-LOYOLA, \\ Viridiana MARTÍNEZ-MARTÍNEZ, María Fernanda RAMÍREZ-CORCHADO \\ and Rosario RODRÍGUEZ-ARNAIZ*
}

\begin{abstract}
Laboratorio de Genética y Evolución, Departamento de Biología Celular, Facultad de Ciencias, Universidad Nacional Autónoma de México, Circuito Esterior s/n, Col. Universidad Nacional Autónoma de México, 04510 Ciudad de México, México

*Autora para correspondencia: rosario.rodriguez@ciencias.unam.mx
\end{abstract}

(Received April 2017, accepted June 2018)

Key words: clomazone, linuron, simazine, somatic mutation and recombination test

\begin{abstract}
The genotoxicity of the herbicides clomazone, linuron and simazine was detected using the somatic wing spot assay of Drosophila melanogaster. For the evaluation of the mutagenic and recombinogenic activities induced by the herbicides two crosses were used: the standard cross (ST) which expresses basal levels of cytochrome P450 enzymes and the high bioactivation cross (HB) with overexpression of P450 genes conferring increased sensitivity to promutagens and procarcinogens. Third-instar larvae were exposed by chronic feeding $(48 \mathrm{~h})$ to three different concentrations of each herbicide. The frequencies of spots per individual in the treated series were compared to the negative concurrent control series (water or $5 \%$ ethanol solution depending on the herbicide). Clomazone showed positive results for small and total spots in both the ST and the HB crosses. Linuron was positive at all concentrations tested for small and total spots in the ST cross while only positive for small and total spots at the highest concentration assayed in the HB cross. Simazine did not produce positive results in the ST cross while it was positive in the HB cross. The bifunctional cross-linking agent mitomycin $\mathrm{C}(\mathrm{MMC}-0.15 \mathrm{mM})$ was used as positive control and produced as expected a significant increase of all types of spots in both crosses. In conclusion, the positive results were due to induced mutations and not by recombinogenic activity, furthermore the significant increase in the frequency of total spots was mainly due to the induction of small single spots.
\end{abstract}

Palabras clave: clomazón, linurón, simacina, ensayo de mutación y recombinación somática

\section{RESUMEN}

La genotoxicidad de los herbicidas clomazón, linurón y simacina se detectó empleando el ensayo somático en alas de Drosophila melanogaster. Para la evaluación de la actividad mutagénica y recombinogénica inducida por los herbicidas se emplearon dos cruzas: la cruza estándar (ST) que expresa niveles basales de enzimas citocromo P450 y 
la cruza de alta bioactivación (HB) que sobreexpresa los genes P450, lo cual le confiere una sensibilidad incrementada para la detección de promutágenos y procarcinógenos. Larvas de tercer estadio se expusieron por alimentación crónica $(48 \mathrm{~h})$ a tres concentraciones diferentes de los tres herbicidas. La frecuencia de manchas por individuo obtenidas en las series tratadas se comparó con los testigos concurrentes (agua o etanol al $5 \%$ dependiendo del herbicida). Los resultados muestran que el clomazón indujo de forma positiva manchas chicas y totales en ambas cruzas. El linurón fue positivo en la cruza ST en todas las concentraciones probadas mientras que solamente fue positivo en la concentración más alta en la cruza HB. La simacina no indujo daño en la cruza ST pero si fueron positivos los resultados en la cruza HB. La mitomicina C (MMC, $0.15 \mathrm{mM}$ ), agente alquilante bifuncional, se empleó como control positivo y produjo un aumento significativo en todos los tipos de manchas en ambas cruzas. En conclusión, los resultados positivos de deben a la actividad mutagénica más no recombinogénica de los herbicidas; más aún, aumento significativo en la frecuencia total de manchas se debe a la inducción de manchas sencillas pequeñas.

\section{INTRODUCTION}

Agriculture production requires the use of pesticide chemicals that are released to the environment on croplands and pastures. More than 1500 chemicals are registered for use in thousands of pesticide formulations, however less than 50 pesticides are commonly applied and some of these have genotoxic properties (Kaya et al. 2000a). Pesticide release into the environment is continuously increasing. To evaluate its potential genotoxic effects toxicologic, mutagenic and carcinogenic evaluations are required. Exposure to pesticides can increase the risk of cancer (Koutros et al. 2015). Some pesticides have genotoxic activity either directly or indirectly which can be caused by the compound itself or by means of the metabolites generated after their biotransformation (Plewa et al. 1984, Plewa and Wagner 1993, Kaya et al. 2000b). The activation of promutagens and procarcinogens is primarily performed by cytochrome P450 enzymes.

The extensive knowledge of the genetics and molecular biology of the model organism Drosophila melanogaster and the long experimental experience with this organism has made it of unique usefulness in mutation research and genetic toxicology. The development of somatic mutation and recombination tests, known by their acronym SMART, have provide a sensitive, rapid and cheap assays for investigation of mutagenic and recombinogenic properties of chemicals (Rodríguez-Arnaiz et al. 1993, 2006, Rodríguez-Arnaiz 2003, Cakir and Sarikaya 2005). The in vivo wing spot test has shown to be a versatile short-term in vivo assay which detects a spectrum of genetic end-points monitored as loss of heterozigosity $(\mathrm{LOH})$, which includes point mutations, deletions, non-disjunction, chromatid loss and also mitotic recombination. The assay uses two genetic markers of the wing: multiple wing hair $(m w h)$ and flare $\left(f l r^{3}\right)$ in the third chromosome. Besides, many of the enzyme activities found in mammals related to biotransformation of chemicals are present in Drosophila larvae and adults, especially the cytochrome P450 and cytochrome oxidase system (Graf et al. 1984, 1989, Graf and van Shaik 1992, Dunkov et al. 1996).

The wide use of herbicides and their potential genetic risk justify their detection for genotoxicity in eukaryotic organisms and particularly with the somatic in vivo wing assay of Drosophila melanogaster, which has been shown to be a very good tool to detect several genetic alterations in a rapid and cheap assay. The herbicides clomazone, linuron and simazine, whose chemical structures are shown in figure 1, are widely used as pre- and post-emergent control of annual and perennial broad leaf and grassy weeds and are applied in the cultivation of agricultural crops such as maize, sorghum, wheat, and sugar cane. Their persistence in soil varies between one to four months (clomazone) to five to 12 months (linuron, simazine) (Galiulin et al. 1978, Mervosh et al. 1995, Navarro et al. 2003).

Clomazone, is a pyridazine herbicide that affects carotenoid biosynthesis in plants. It is metabolized in soybean through dealkylation and conjugation of the resulting chlorobenzyl moiety to form a glycoside (Elnaggar et al. 1992). Clomazone did not produce any genotoxic effect in the Salmonella typhimurium reversion-Ames test (US EPA 2007) although it was positive in inducing micronucleus in erythrocytes from farming communities of fishes (Salvagni et al. 2011) and also induced oxidative stress in human erythrocytes in vivo (Santi et al. 2011). 
Clomazone<smiles>CC1(C)CON(Cc2ccccc2Cl)C1=O</smiles>

Linuron<smiles>CON(C)C(=O)Nc1ccc(Cl)c(Cl)c1</smiles>

Simazine

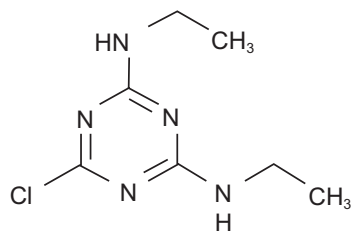

Fig. 1. Structural formula of the herbicides tested

Linuron is a phenyl-urea herbicide that acts on target plants by inhibiting the photosystem reaction center, blocking electron transport and thereby disrupting photosynthesis (Jurado et al. 2011, Santos et al. 2014). The degradation pathways of linuron initiate with $\mathrm{N}$-demethylation and N-demethoxylation (Pascal-Lorber et al. 2010). No genotoxicity has been shown in several in vivo and in vitro assays: gene mutations in CHO cells, Salmonella typhimurium, unscheduled DNA synthesis and in vivo rat bone marrow micronuclei test (US EPA 1988). However, linuron was cytotoxic in rat cells treated with the commercial formulation. This cytotoxicity was accompanied by the induction of single-strand breaks in liver as seen by the alkaline elution assay (Scassellati-Sforzini et al. 1997). Diuron, also a phenyl-urea herbicide as linuron, showed to induce sex-linked recessive lethals in Drosophila melanogaster (Rodríguez-Arnaiz et al. 1989) and recently has been shown to be genotoxic in the wing spot assay and in a new developed wing disk comet assay demonstrating a positive correlation between both assays (Peraza-Vega et al. 2016).

Simazine, a chloro-s-triazine compound, inhibits photosystem II in the chloroplast. It has been shown to be an endocrine disruptor that induced mammary tumors in rats through an increase of prolactin levels (O'Connor et al. 2000, Sanderson 2006). Simazine did not induce any dose related increase in DNA damage in the alkaline single cell assay (Tennant et al. 2001). In the Tradescantia hair stamen test the herbicide induced pink mutation events (Patussi and Bündchen 2013). Maternal exposure to simazine inhibits the growth of female offspring via disturbance of cellular apoptosis and proliferation (Park et al. 2014). The herbicide is biotransformed by P450 enzymes to form a major chlorinated metabolite diamino-s-chlorotriazine, which is detectable in urine, serum, and various tissues of exposed animals (Hanioka et al. 1999).

The purpose of this work is to assess the genotoxicity testing of clomazone, linuron and simazine using the wing somatic spot assay of Drosophila melanogaster employing the standard cross (ST) which expresses basal levels of cytochrome P450 enzymes and the high bioactivation cross (HB) with constitutive overexpression of 450 genes. The data obtained will give information about the biotransformation activity of these herbicides. Genotoxic damage in single spots could be due to point mutations, chromosomal breakage and mitotic recombination while twin spots are produced only by mitotic recombination.

\section{MATERIALS AND METHODS}

\section{Chemical compounds}

Commercial herbicides clomazone (Command 36), linuron (Linurex $50 \mathrm{WP}$ ) and simazine (Simanex $50 \mathrm{JC})$ were obtained from the pesticide store Agroquímicos El Galeón located at Xochimilco, Mexico City. Mitomycin C (MMC, 50-07-7) was purchased from Sigma-Aldrich Mexico.

\section{Experimental concentrations}

Median lethal concentrations $\left(\mathrm{LC}_{50}\right)$ of the herbicides were obtained by treating one hundred ST third instar larvae of $72 \pm 3 \mathrm{~h}$ (Graf et al. 1984) with different concentrations of each herbicide. Commercial herbicides were prepared at different concentrations. For Clomazone, 1, 3, 6, 10 and $20 \%$ was dissolved in distilled water. For Linuron the concentrations tested were $0.07,0.15,0.3,0.62$ and $1.24 \%$ dissolved in 5 $\%$ ethanol solution. Simazine was proved at 1, 2.5, 5 and $10 \%$ dissolved in water. Larvae were treated in vials with Drosophila instant medium (Formula 4-24, Carolina Biological Supply Co., Burlington, $\mathrm{NC}$, USA) rehydrated with the herbicide concentrations until imago emergence. Three replicas were 
performed. Mortality percentage was calculated after imago emergence and a linear, polynomial and/or logarithmic regression was performed for each herbicide. The concentrations assayed in the experiments were based on the viability obtained.

\section{Larval feeding}

Eggs derived from both crosses (ST and HB) were collected after $8 \mathrm{~h}$ oviposition in well-yeasted culture bottles medium. Three days later, when the larvae were $72 \pm 3 \mathrm{~h}$ old, they were washed with tap water through a fine-meshed stainless steel strainer and then used for chronic feeding: small vials with $1.5 \mathrm{~g}$ Drosophila Instant Medium (Carolina Biological Supply Co., Burlington, NC, USA) and $5 \mathrm{ml}$ of the respective herbicide solution were used. Negative water and solvent controls were always included. The larvae were fed on this medium for the rest of their development, which corresponds to approximately 48 h (van Schaik and Graf 1993).

\section{Strains}

The following three Drosophila melanogaster strains were used for the wing spot test: (1) flare-3 $\left(f l r^{3} / \operatorname{In}(3 \mathrm{LR}) \mathrm{TM} 3\right.$, rip $\left.^{\mathrm{p}} \operatorname{sep} b x^{34 \mathrm{e}} e^{\mathrm{s}} B d^{\mathrm{S}}\right)$; (2) Oregonflare-3(ORR) $f r^{3} / \operatorname{In}$ (3LR)TM3, ri p pep $b x^{34 \mathrm{e}} e^{\mathrm{s}}$ $\left.B d^{\mathrm{S}}\right)$, and (3) multiple wing hairs $(m w h / m w h)$. For detailed information on the genetic markers see Lindsley and Zimm (1992). Two versions of SMART were used: the standard cross (ST) in which virgin females flare-3 $\left(\operatorname{fr}^{3} / \operatorname{In}(3 \mathrm{LR}) \mathrm{TM} 3, B d^{\mathrm{S}}\right.$ strain were mated with $m w h / m w h$ males or the high bioactivation cross in which females OR/ORR $A l r^{3} / \operatorname{In}(3 \mathrm{LR}) \mathrm{TM} 3, B d^{\mathrm{S}}$ were crossed with $m w h / m w h$ males. The ORR strain has chromosomes 1 and 2 from a DDT-resistant Oregon R (R) line (Dapkus and Merell 1997, Frölich and Würgler 1989, 1990) responsible for a high constitutive level of cytochrome P450 enzymes.

\section{Somatic mutation and recombination test}

The flies were collected from the treatment vials on day 10 to 12 after laying and stored in $70 \%$ ethanol. The wings of progeny with the marker-heterozygous $\left(m w h+/+f r^{3}\right)$ were mounted in Faure's solution. Both surfaces of the wings were scored under a compound microscope at $400 \mathrm{X}$ magnification for the occurrence of spots. For each treatment 60 flies were analyzed. In each case the size of the spot was determined by counting the number of wing cells exhibiting the $m w h$ or the $f r^{3}$ phenotype. Three categories of spots were recorded separately: (1) $m w h$ single spots, (2) $f r^{3}$ single spots, and (3) twin spots with adjacent $m w h$ and $f r^{3}$ areas. Because there is a correlation between the time of induction of a genetic change in the somatic cells and the size of the resulting spot (Graf 1995), spot sizes are also recorded in addition to spot frequencies. Single spots are produced either by somatic point mutations, deletions and mitotic recombinations occurring between the two markers. Twin spots are produced exclusively by mitotic recombination occurring between the proximal marker $\mathrm{fl}^{3}$ and the centromere of chromosome 3 (Graf et al. 1984, 1989).

\section{Statistical analysis}

Wing-spot data were evaluated with the computer program SMART based on the Kastenbaum-Bowman test $(\mathrm{P} \leq 0.05)$ (Würgler unpublished). For the statistical analysis the spots were grouped in the following three types: (1) small single spots of one or two cells in size ( $m w h$ or $\left.f r^{3}\right),(2)$ large single spots of three or more cells, and (3) twin spots with an $m w h$ and an $\mathrm{fl}^{3}$ clone. These three types of spot are evaluated separately. For the frequencies of each type of spot (small and large single spots or twin spots) and the total frequency of spots per wing for each treatment, a multiple-decision procedure was used to decide whether a result is positive, weakly positive, inconclusive or negative and were compared pair-wise with negative or positive mutagen controls frequencies, or inversely, using the SMART computer program (Frei and Würgler 1988). The non-parametric U-test of Mann-Whitney and Wilcoxon $(\alpha=\beta=0.05$, one sided) was used in order to exclude false positive or negative diagnoses. The U-test takes into account the rank values in controls and treatments and considers over-dispersion in a non-normal distribution. Nonsignificant results mean a lack of sensitivity or an absence of genotoxicity at the concentration tested in the wing spot test and significant results represent genotoxicity when the treatment frequencies are higher than the control (Frei and Würgler 1995).

\section{RESULTS AND DISCUSSION}

Before starting the genotoxicity experiments, toxicity studies were performed in order to determine the concentrations to be tested in the wing spot test. Based on the means of survival of the larvae of Drosophila melanogaster, the $\mathrm{LC}_{50}$ for each of the herbicides was determined. These data were plotted (survival averages vs. concentration) and are shown in figures 2, $\mathbf{3}$ and $\mathbf{4}$ (herbicides are represented by black diamonds); then the different trend lines (linear, polynomial and/or logarithmic 

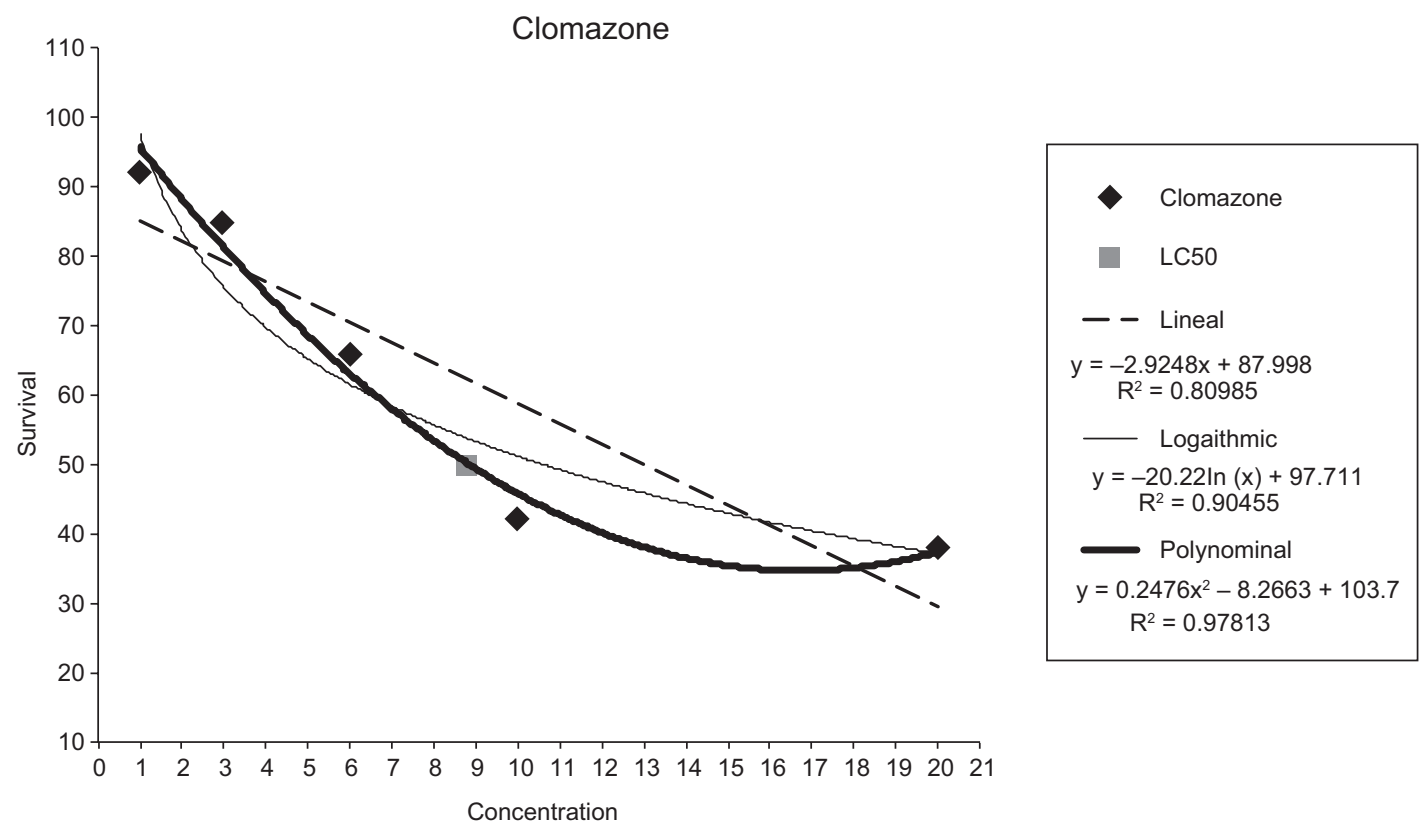

Fig. 2. Percentage of mortality obtained for clomazone

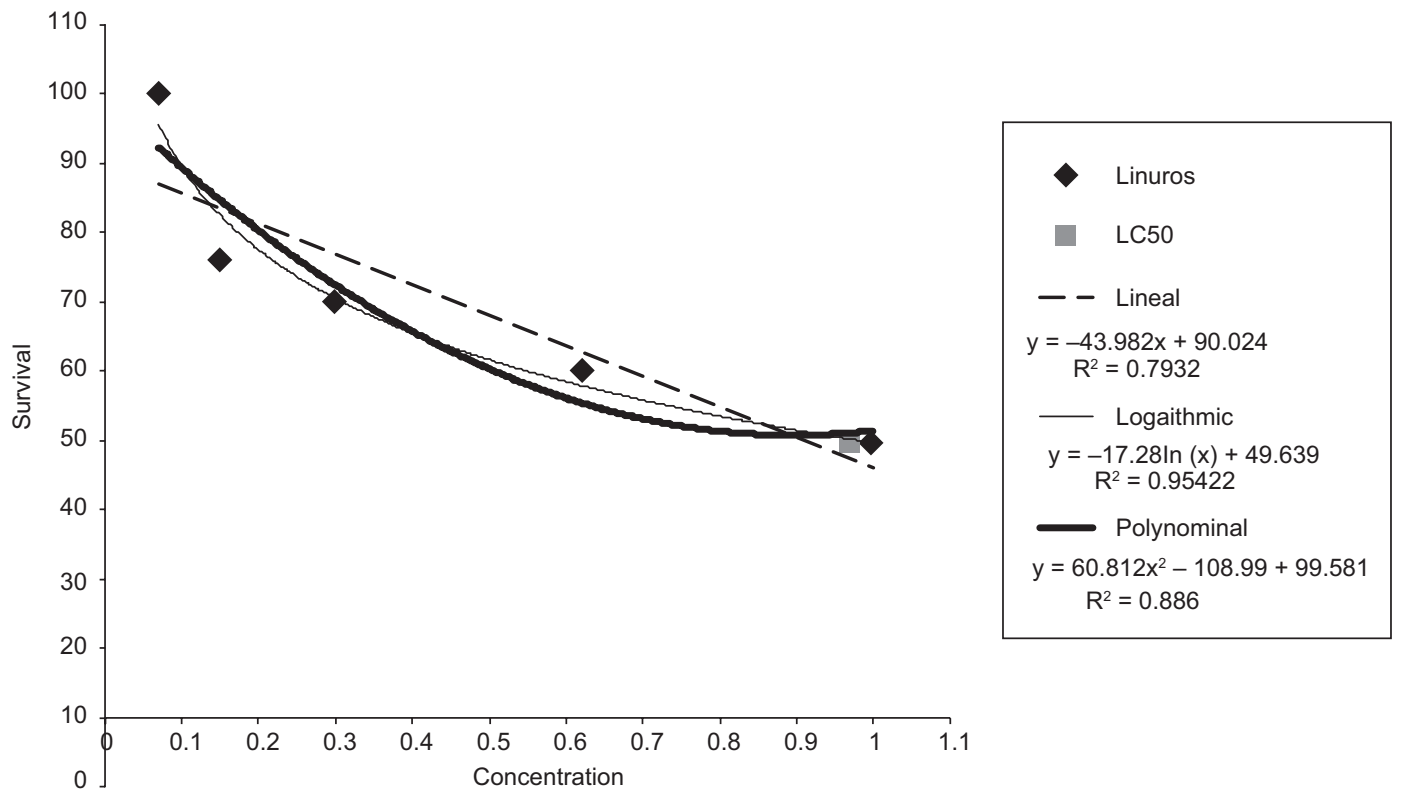

Fig. 3. Percentage of mortality obtained for linuron

regression), as well as the equation for each function, were obtained in the Excel program. The $\mathrm{LC}_{50}$ was calculated by the quadratic equation $\left(a x^{2}+b x\right.$ $+c=0$ ) for the polynomial regressions (simazine and clomazone) and with the function $\operatorname{In}\left(e^{\mathrm{x}}\right)=x$ for the logarithmic regression (linuron). In each case, the model whose correlation was highest was used. Finally, an interpolation was made in the graph 8 from the data obtained in the equations with the help of the Excel program. For clomazone a polynomial regression was performed with $\mathrm{R}^{2}=0.9781$ and a final value of $\mathrm{LC}_{50}=9 \%$ (Fig. 2); for linuron the value obtained after the logarithmic model calculations was $0.98 \%\left(\mathrm{R}^{2}=0.9562\right.$, Fig. 3) and for simazine the regression value gave a final value of $\mathrm{LC}_{50}=5.6 \%\left(\mathrm{R}^{2}=0.991\right.$, Fig. 4$)$. 


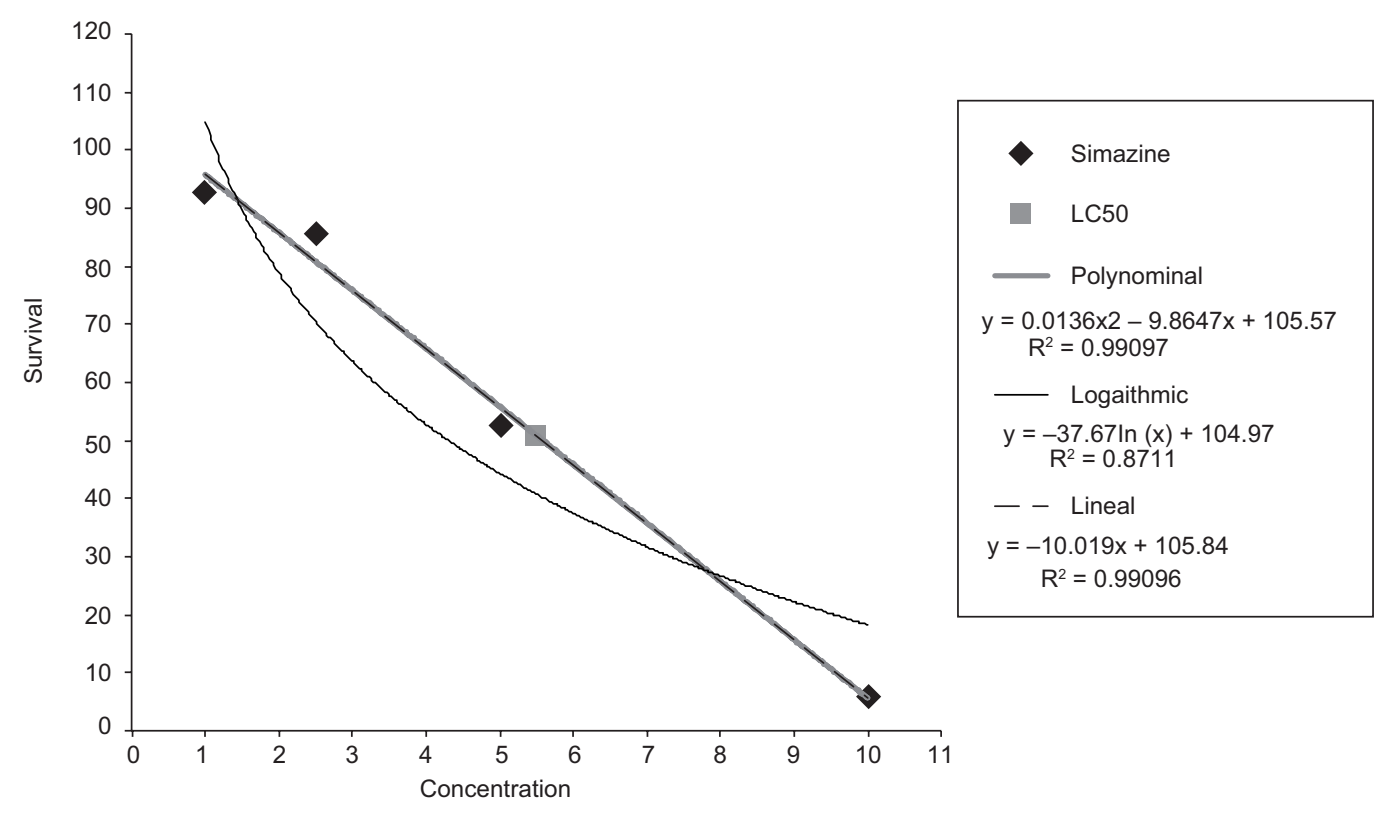

Fig. 4. Percentage of mortality obtained for simazine

Since human exposure to herbicides is not only limited to the active principles but also due to all chemicals present in the commercial formulations, we tested these for all three herbicides, which have shown (with the exception of linuron) not to be toxic. Consequently, we were able to test concentrations with percentages as high as 1 to $10 \%$ (clomazone, simazine); linuron was toxic for Drosophila and tested in a percentage range from 0.25 to $1 \%$.

For each compound and treatment three independent experiments were performed with concurrent positive and negative solvent controls. The data presented are the sum of these experiments, which were pooled after verifying the homogeneity of the three data sets. For both the ST and the HB crosses using the $m w h+1+f l r^{3}$ transheterozygous flies, three different concentrations of each herbicide were tested in parallel with negative (water or ethanol $5 \%$ solution) and positive (MMC $0.15 \mathrm{mM}$ ) controls to ensure the validity of the results obtained. Table I summarizes the results obtained after chronic exposure to the three herbicides. It can be noted that the majority of spots recovered after treatment were single spots of one or two cells, which could be due to induced genotoxicity at a late stage of development of the wing imaginal discs due to delayed metabolism. In this study, twin spots were not significantly produced at the concentrations assayed. The majority of spots recovered were $m w h$ and the data obtained about the mean number of cell division cycles falls between the number of cell division cycles that occurred at the start of third instar larvae and pupation.

Drosophila larvae can metabolize genotoxins in a similar manner as mammals do. Hence the importance of Drosophila as a model organism studying compounds that required biotransformation to produce genotoxic effects. To comparatively evaluate the genotoxicity of the herbicides, two versions of the Drosophila wing assay were used: the ST and the HB crosses by treating directly larvae with the herbicides.

Clomazone showed a significant positive result at the higher concentrations tested giving almost the same results in both the ST and the HB crosses. The significant increases observed were from small and total spots, no twin spots were produced. Thus, in both strains clomazone induced similar levels of spots and nearly identical levels of total spots. These results suggest that the parental form of clomazone is the active form of the herbicide and/or clomazone is converted to the same toxic metabolites by both fly strains. This effect could be related to the positive results obtained for the herbicides molinate, trifuralin and triasulfuron, or its metabolites, that induced an increase of single and total spots in both strains with no evidence of a recombinogenic activity (Hayes and Laws 1990, Kale et al. 1995, Kaya et al. 2004, Heres-Pulido et al. 2008). Previous work reported for the genotoxicity of clomazone showed different results depending on the genetic assay used. In bacterial assays the result was clearly negative while in 
TABLE I. SUMMARY OF RESULTS OBTAINED IN TRANS-HETEROZYGOUS PROGENY OF ST AND HB CROSSES AFTER CHRONIC TREATMENT OF LARVAE WITH THE THREE HERBICIDES

\begin{tabular}{|c|c|c|c|c|c|c|c|}
\hline \multirow{3}{*}{$\begin{array}{l}\text { Compound } \\
\text { concentration } \\
(\mathrm{mM} \text { or } \%)\end{array}$} & \multirow{3}{*}{$\begin{array}{c}\text { Cross }^{\mathrm{a}} \\
\text { and number } \\
\text { of flies }\end{array}$} & \multicolumn{4}{|c|}{ Spots per fly (Number of spots) Statistical diagnoses ${ }^{b}$} & \multirow{3}{*}{$\begin{array}{l}\text { Spots with } \\
\text { mwh clone }\end{array}$} & \multirow{3}{*}{$\begin{array}{c}\text { Mean number } \\
\text { of cell division } \\
\text { cycles }\end{array}$} \\
\hline & & $\begin{array}{l}\text { Small single } \\
\text { spots } \\
(1-2 \text { cells })\end{array}$ & $\begin{array}{l}\text { Large single } \\
\text { spots } \\
(>2 \text { cells })\end{array}$ & $\begin{array}{l}\text { Twin } \\
\text { spots }\end{array}$ & $\begin{array}{l}\text { Total } \\
\text { spots }\end{array}$ & & \\
\hline & & $\mathrm{m}=2$ & $\mathrm{~m}=5$ & $\mathrm{~m}=5$ & $\mathrm{~m}=2$ & & \\
\hline CLOMAZONE & ST & & & & & & \\
\hline MMC $0.15 \mathrm{mM}$ & 6 & $45.50(273)+$ & $18.17(109)+$ & $4.17(25)+$ & $67.83(407)+$ & 405 & 2.14 \\
\hline Negative control & 60 & $0.27(16)$ & $0.05(3)$ & $0.02(1)$ & $0.33(20)$ & 19 & 1.58 \\
\hline $2.50 \%$ & 60 & $0.32(19) \mathrm{i}$ & $0.08(4) \mathrm{i}$ & $0.07(4) \mathrm{i}$ & $0.47(28) \mathrm{i}$ & 28 & 2 \\
\hline $5 \%$ & 60 & $0.58(35)+$ & $0.07(4) \mathrm{i}$ & $0.02(1) \mathrm{i}$ & $0.67(40)+$ & 38 & 1.63 \\
\hline $10 \%$ & $\begin{array}{r}60 \\
\text { HB }\end{array}$ & $0.57(34)+$ & $0.07(4) \mathrm{i}$ & $0.02(1) \mathrm{i}$ & $0.65(39)+$ & 39 & 1.64 \\
\hline MMC $0.15 \mathrm{mM}$ & 6 & $57.50(345)+$ & $22.00(132)+$ & $3.83(123)+$ & $83.33(500)+$ & 490 & 2.02 \\
\hline Negative control & 60 & $0.30(18)$ & $0.02(1)$ & $0.00(0)$ & $0.32(19)$ & 19 & 1.32 \\
\hline $2.50 \%$ & 60 & $0.40(24) \mathrm{i}$ & $0.06(3) \mathrm{i}$ & $0.02(1) \mathrm{i}$ & $0.46(28) \mathrm{i}$ & 28 & 1.82 \\
\hline $5 \%$ & 60 & $0.50(30) \mathrm{i}$ & $0.12(7)+$ & $0.02(1) \mathrm{i}$ & $0.64(38)+$ & 38 & 1.92 \\
\hline $10 \%$ & 60 & $0.58(35)+$ & $0.08(5) \mathrm{i}$ & $0.02(1) \mathrm{i}$ & $0.68(41)+$ & 39 & 1.67 \\
\hline LINURON & ST & & & & & & \\
\hline MMC $0.15 \mathrm{mM}$ & 6 & $45.50(273)+$ & $18.17(109)+$ & $4.17(25)+$ & $67.83(407)+$ & 405 & 2.14 \\
\hline Ethanol 5\% & 60 & $0.37(22)$ & $0.03(2)$ & $0.00(0)$ & $0.40(24)$ & 23 & 1.52 \\
\hline $0.25 \%$ & 60 & $0.57 / 34) \mathrm{i}$ & $0.13(8) \mathrm{i}$ & $0.00(0)$ & $0.70(42)+$ & 41 & 1.8 \\
\hline 0.5 & 60 & $0.67(40)+$ & $0.12(7) \mathrm{i}$ & $0.02(1) \mathrm{i}$ & $0.80(48)+$ & 46 & 1.72 \\
\hline \multirow[t]{2}{*}{1} & 60 & $0.70(42)+$ & $0.08(5) \mathrm{i}$ & $0.00(0)$ & $0.78(47)+$ & 46 & 1.67 \\
\hline & $\mathrm{HB}$ & & & & & & \\
\hline MMC $0.15 \mathrm{mM}$ & 6 & $57.50(345)+$ & $22.00(132)+$ & $3.83(123)+$ & $83.33(500)+$ & 490 & 2.02 \\
\hline Ethanol 5\% & 60 & $0.33(29)$ & $0.12(7)$ & $0.02(19$ & $0.47(28)$ & 26 & 1.92 \\
\hline $0.25 \%$ & 60 & $0.48(29) \mathrm{i}$ & $0.02(1)-$ & $0.03(2) \mathrm{i}$ & $0.53(32)-$ & 31 & 1.68 \\
\hline 0.5 & 60 & $0.48(29) \mathrm{i}$ & $0.10(6)-$ & $0.00(0)$ & $0.58(35)-$ & 33 & 1.7 \\
\hline 1 & 60 & $0.77(46)+$ & $0.10(6)-$ & $0.00(0)$ & $0.87(52)+$ & 51 & 1.61 \\
\hline SIMAZINE & $\mathrm{ST}$ & & & & & & \\
\hline MMC $0.15 \mathrm{mM}$ & 6 & $45.50(273)+$ & $18.17(109)+$ & $4.17(25)+$ & $67.83(407)+$ & 405 & 2.14 \\
\hline Negative Control & 60 & $0.17(10)$ & $0.02(1)$ & $0.00(0)$ & $0.18(11)$ & 10 & 1.3 \\
\hline $1 \%$ & 60 & $0.17(19)-$ & $0.05(3) \mathrm{i}$ & $0.03(2) \mathrm{I}$ & $0.25(15)-$ & 15 & 1.93 \\
\hline $2.50 \%$ & 60 & $0.27(16) \mathrm{I}$ & $0.05(3) \mathrm{i}$ & $0.00(0)$ & $0.32(19)-$ & 19 & 1.74 \\
\hline \multirow[t]{2}{*}{$5 \%$} & 60 & $0.28(17) \mathrm{I}$ & $0.07(4) \mathrm{i}$ & $0.00(0)$ & $0.35(21)-$ & 21 & 1.86 \\
\hline & HB & & & & & & \\
\hline MMC $0.15 \mathrm{mM}$ & 6 & $57.50(345)+$ & $22.00(132)+$ & $3.83(123)+$ & $83.33(500)+$ & 490 & 2.02 \\
\hline Negative control & 60 & $0.27(16)$ & $0.07(4)$ & $0.00(0)$ & $0.33(20)$ & 20 & 1.85 \\
\hline $1 \%$ & 60 & $0.43(26) \mathrm{i}$ & $0.03(2)-$ & $0.02(1) \mathrm{i}$ & $0.48(29) \mathrm{i}$ & 29 & 1.39 \\
\hline $2.50 \%$ & 60 & $0.53(32)+$ & $0.05(3)-$ & $0.02(1)-$ & $0.60(36)+$ & 35 & 1.77 \\
\hline $5 \%$ & 60 & $0.53(32)+$ & $0.07(4)-$ & $0.00(0)$ & $0.60(36)+$ & 36 & 1.69 \\
\hline
\end{tabular}

${ }^{a} \mathrm{ST}$ (standard cross), HB (high bioactivation cross); ${ }^{b}$ statistical diagnoses according to Frei and Würgler (1988, 1995); m: minimal risk multiplication factor for the assessment of negative results. For the final statistical diagnoses of all outcomes: $+=$ positive; $-=$ negative; $\mathrm{i}=$ inconclusive, and $\mathrm{w}^{+}=$weakly positive with the standard SMART software based in the conditional binomial test according to Kastenbaum-Bowman significance levels $(a=b=0.05)$ (Frei and Würgler 1988). The non-parametric Mann-Whitney Wilcoxon U-test with significance levels ( $a=b=0.05$, one-sided) was used in order to exclude false positive or and negative diagnoses (Frei and Würgler 1995) 
the micronucleus fish assay it was positive and also induced oxidative stress in the in vivo erythrocyte human assay (Salvagni et al. 2011, Santi et al. 2011) showing the possible role of ROS toxicity mechanisms induced by clomazone in humans.

Linuron clearly increased the frequency of small and total spots at all concentrations tested in the ST cross while a statistical significant result was obtained only at the highest $(1 \%)$ concentration tested in the HB cross. These results could be related to investigations with other types of herbicides performed to test their genotoxicity in the wing spot test: alachlor, atrazine and paraquat were only positive in the ST cross (Torres et al. 1992), as well as 2,4,5-trichlorophenoxyacetic acid, maleic hydrazide and glyphosate (Kaya et al. 2000b). Recently the phenyl-urea herbicide diuron, chemically related to linuron, has been shown to induce similar results in the wing spot test of Drosophila: a positive dose-response effect in the ST cross while only positive at the highest concentration in the HB cross (Peraza-Vega et al. 2016). Additionally, the genotoxic effect detected for diuron in the wing spot test was related by these authors to the DNA damage induced in the wing imaginal disk comet assay. These results showed that the HB cross is able to detoxify both herbicides at least in the lower concentrations, which could be related to the CYP level expression in both crosses. The present study shows that direct chronic treatment of third instar larvae with linuron produced a clear dose-response effect and induced statistical significant spot frequencies at all concentrations tested in the ST cross, while in the HB series the same effect was obtained only at the highest concentrations assayed, which could be related to the CYPs levels difference present in both crosses.

It has been shown that phenyl-urea herbicides are able to induce CYP expression of the isoform CYP3A4 in mammals (Abass et al. 2012). This enzyme has a homologous form in Drosophila melanogaster CYP9F2 (HomoloGene 2015). Both enzymes are demethylases. Probably, this enzyme with other induced isoforms (like members of the CYP6 family) could be responsible of the biotransformation of the herbicide. The mammalian P450 isoforms CYP1A1 CYP1A2, CYP2C19 and CYP2D6 involved in the detoxification of several polycyclic aromatic hydrocarbons and therapeutic drugs (Nebert et al. 2013) have been shown to have a homologous form in Drosophila melanogaster: Cyp18al (Cunningham et al. 2014, HomoloGene 2015). This gene may be responsible for the detoxification of linuron at the lower concentrations in the HB cross.
Previous studies have shown that linuron was not toxic for both Salmonella typhimurium and Chinese hamster ovary cells (US EPA 2010) but induced micronuclei in the human cytokinesis block micronucleus assay using lymphocytes treated in vitro (Papapaulou 2001). In rat bone marrow erythrocyte micronucleus test, no increase of micronucleus was observed in rats treated with the commercial formulation of linuron, but it showed to induce DNA single strand breaks in the liver as seen by the alkaline elution assay (Scassellati-Sforzolini et al. 1997).

The chlorotriazene herbicide simazine induced a significant positive effect in small single spots as well as in total spots only in the HB cross, but no difference in these inductions was noted between the two highest concentrations assayed ( 2.5 and 5 $\%)$. Comparable results were obtained when propanil, bentazon and basagran were tested in the wing somatic mutation and recombination test where these herbicides gave positive results only in the HB cross (Kaya et al. 2000a, 2004, Heres-Pulido et al. 2008). This positive response does not follow a direct doseresponse relationship and corroborates the fact that the herbicide is metabolized through P450 enzyme in vivo and in vitro in mammals by $\mathrm{N}$-monodealkylation and isopropylhydroxilation (Adams et al. 1990, Lang et al. 1996, Hanioka et al. 1999). In plants it has been shown that the triazine herbicide atrazine interferes with cell division producing chromosomal abnormalities (Liang and Liang 1972) and mutagenic and recombinogenic activity in Aspergillus nidulans (Benigni et al. 1979, Kappas 1988). In Tradescantia 4430 clone stamen hair mutation the triazine herbicides triazene and simazine induced pink mutation events (Patussi and Bündchen 2013).

The results here reported add information about the genotoxicity of several herbicides previously reported. Atrazine, alachlor and paraquat induced significant increases in single spots (Torres et al. 1992), while the herbicides $2,4,5-\mathrm{T}$, maleic hydrazine and glyphosate increased the frequency for small single spots only in ST cross (Kaya et al. 2004) and propanil appeared to be more genotoxic in HB than in ST (Heres-Pulido et al. 2008).

\section{CONCLUSION}

In conclusion, the data shown herein demonstrates that clomazone was genotoxic in both crosses while linuron was clearly positive in the ST cross and simazine induced a genotoxic effect only in the HB cross. The positive results obtained in this study add infor- 
mation on the existing data on the induced genotoxic effects of herbicides tested in the wing spot test of Drosophila. Additionally, the usefulness of strains with high levels of metabolic activation (HB) besides the strains with basal levels of P450 enzymes (ST) adds information for the genotoxic evaluation of pesticides.

\section{REFERENCES}

Abass K., Lämsä V., Reponen P., Küblbeck J., Honkakosk, P., Mattila S., Pelkonen O. and Hakkola J. (2012). Characterization of human cytochrome $\mathrm{P} 450$ induction by pesticides. Toxicology 294 (1),17-26.

DOI: $10.1016 /$ j.tox.2012.01.010

Adams N.H., Levi P.E. and Hodgson E. (1990). In vitro studies of the metabolism of atrazine, simazine and terbutryn in several vertebrate species. J. Agric. Food Chem. 38 (6), 1411-1417. DOI: 10.1021/jf00096a025

Benigni R., Bignami M., Camoni I., Carere A., Conti G., lachetta R., Morpurgo G. and Ortali V.A. (1979). A new in vitro method for testing plant metabolism in mutagenicity studies. J. Toxicol. Environ. Health 5 (5), 809-819. DOI: $10.1080 / 15287397909529791$

Cakir S. and Sarikaya R. (2005). Genotoxicity testing of some organophosphate insecticides in the Drosophila wing spot. Food Chem. Toxicol. 43 (3), 443-450.

DOI: $10.1016 /$ j.fct.2004.11.010

Cunningham F., Amode M.R., Barrell D., Beal K., Billis K., Brent S., Carvalho-Silva D., Clapham P., Coates G., Fitzgerald S., Gil L., García Girón C., Gordon L., Hourlier T., Hunt E., Janacek S., Johnson N., Juettemann T., Kähäri A., Keenan S., Martin F., Maurel T., McLaren W., Murphy D., Nag R., Overduin R., Parker A., Patricio M., Perry E., Pignatelli M., Singh Riat H., Sheppard D., Taylor K., Thormann A., Vullo A., Wilder S., Zadissa A., Aken B., Birney E., Harrow J., Kinsella R., Muffato M., Ruffier M., Searle S., Spudich G., Trevanion S., Yates A., Zerbino D. and Flicek P. (2014). Ensembl (2015). Nucleic Acids Res. (database issue), D662-9. DOI: 10.1093/nar/gku1010

Dapkus J. and Merell D.S. (1977). Chromosomal analysis of DDT-resistence in a long term selected population of Drosophila melanogaster. Genetics 87 (4), 685-697.

Dunkov B., Rodríguez-Arnaiz R., Pittendrigh B., Frenchconstant F. and Feyereisen R. (1996). Cytochrome P450 gene clusters in Drosophila melanogaster. Mol. Gen. Genet. 251 (3), 290-297.

DOI: $10.1007 / \mathrm{BF} 02172519$

Elnaggar S.F., Creekmore R.W., Schocken M.J., Rosen R.T. and Robinson R.A. (1992). Metabolism of clomazone herbicide in soybean. J. Agr. Food Chem. 40 (5), 880-883. DOI: $10.1021 /$ jf00017a036
Frei H. and Würgler F.E. (1988). Statistical methods to decide whether mutagenicity test data from Drosophila assays indicate a positive, negative or inconclusive result. Mutat. Res. 203 (4), 297-308.

DOI: 10.1016/0165-1161(88)90019-2

Frei H. and Würgler F.E. (1995). Optimal experimental design and sample size for the statistical evaluation of data from somatic mutation and recombination tests (SMART) in Drosophila. Mutat. Res. 334 (2), 247-258.

DOI: 10.1016/0165-1161(95)90018-7

Frölich A. and Würgler F.E. (1989). New tester strain with improved activation capacity for Drosophila wing-spot test. Mutat. Res. 216 (3), 179-187.

DOI: 10.1016/0165-1161(89)90003-4

Frölich A. and Würgler F.E. (1990). Drosophila wing spot test: improved detectability of genotoxicity of polycyclic aromatic hydrocarbons. Mutat. Res. 234 (2), 71-80. DOI: 10.1016/0165-1161(90)90033-K

Galiulin R.V., Sokolov M.S., Pachepskii Y.A. and Ryzhaya M.A. (1978). Effect of some ecological factors of degradation of propanil, linuron, and their transformation product 3,4-dichloroaniline in soil. Biol. Bull. Acad. Sci. USSR. 5 (5), 546-559.

Graf U., Würgler F.E., Katz A.J., Frei H., Juon H., Hall C.B. and Kale P.G. (1984). Somatic mutation and recombination test in Drosophila melanogaster. Environ. Mutagen. 6 (2), 153-188. DOI: $10.1002 / \mathrm{em} .2860060206$

Graf U., Frei H., Kagi A., Katz A.J. and Würgler F.E. (1989). Thirty compounds tested in the Drosophila wing spot test. Mutat. Res. 222 (4), 359-373.

DOI: $10.1016 / 0165-1218(89) 90112-2$

Graf U. and van Shaik N. (1992). Improved high bioactivation cross for the wing somatic mutation and recombination test in Drosophila melanogaster. Mutat. Res. 271 (1), 59-67. DOI: 10.1016/0165-1161(92)90032-H

Graf U. (1995). Analysis of the relationship between age of larvae at mutagen treatment and frequency and size of spots in the wing somatic mutation and recombination test in Drosophila melanogaster. Experientia 51 (2), 168-173. DOI: 10.1007/BF01929364

Hanioka N., Jinno H., Tanaka-Kagawa T., Nishimura T. and Ando M. (1999). In vitro metabolism of simazine, atrazine and propazine by hepatic cytochrome $\mathrm{P} 450$ enzymes of rat, mouse and guinea pig, and oestrogenic activity of chlorotriazines and their main metabolites. Xenobiotica 29 (12), 1213-1226.

DOI: $10.1080 / 004982599237895$

Hayes W.J. and Laws I.R. (1990). Handbook of pesticide toxicology. Vol 3. Classes of pesticides. Academic Press, New York, USA, 949 pp. 
Heres-Pulido M. E., Lombera-Hernández S., DueñasGarcía I., Perales-Canales I., Castañeda-Partida L., Rocha-Ortiz, C. Flores-Maya A., Duran-Díaz A and Graf U. (2008). Genotoxicity of triasulfuron in the wing spot test of Drosophila melanogaster is modulated by winter wheat seedlings. Mutat. Res. Genet. Toxicol. Environ. Mutagen. 653 (1), 70-75.

DOI: 10.1016/j.mrgentox.2008.03.005

HomoloGene (2015). National Center for Biotechnology Information [online]. https://www.ncbi.nlm.nih.gov/ homologene/?term=CYP9F2/111391 16/01/2017

Jurado A.S., Fernandes M.A.S., Videira R.A., Peixora E.P. and Vicente J.A.F. (2011). Herbicides: The face and the reverse of the coin. An in vitro approach to the toxicity of herbicides in non-target organisms. In: Herbicides and the environment (Kortekamp A., Ed.). InTech Open Access Book Publishing, 3-44. DOI: $10.5772 / 12976$

Kale P.G., Petty B.T., Walker J.B., Ford N., Dehkordi S., Tarasia B.O., Tasie R., Kale R. and Solni Y.R. (1995). Mutagenicity testing of nine herbicides and pesticides currently used in agriculture. Environ. Mol. Mutagen. 25 (2), 148-153. DOI: 10.1002/em.2850250208

Kappas A. (1988). On the mutagenic and recombinogenic activity of certain herbicides in Salmonella typhimurium and in Aspergillus nidulans. Mutat. Res. 204 (4), 615-621. DOI: 10.1016/0165-1218(88)90064-X

Kaya B., Yanikoglu A., Creus A. and Marcos R. (2000a). Genotoxicity testing of five herbicides in the Drosophila wing spot test. Mutat. Res. 465 (1), 77-84. DOI: 10.1016/S1383-5718(99)00214-4

Kaya B., Creus A., Yanikoğlu A., Cabré O. and Marcos R. (2000b). Use of the Drosophila wing spot test in the genotoxicity testing of different herbicides. Environ. Mol. Mutagen. 36 (1), 40-46.

DOI: $10.1002 / 1098-2280(2000) 36: 1<40$ :AIDEM6>3.0.CO;2-K

Kaya B., Marcos R., Yanikoğlu A. and Creus A. (2004). Evaluation of the genotoxicity of four herbicides in the wing spot test of Drosophila melanogaster using two different strains. Mutat. Res. 557 (1), 53-62.

DOI: $10.1016 /$ j.mrgentox.2003.09.010

Koutros S., Langseth H., Grimsrud T.K., Barr D.B., Vermeulen R., Portengen L., Wacholder S., Freeman L.E., Blair A., Hayes R.B., Rothman N. and Engel L.S. (2015). Prediagnostic serum organochlorine concentrations and metastatic prostate cancer: A nested case-control study in the Norwegian Janus Serum Bank Cohort. Environ. Health. Persp. 123 (9), 867-872.

DOI: $10.1289 /$ ehp. 1408245

Lang D., Criegee D., Grothusen A., Saalfrank R.W. and Böcker R.H. (1996). In vitro metabolism of atrazine, terbuthylazine, ametryne and teerbutryne in rats, pigs and humans. Drug Metab. Dispos. 24 (8), 859-865.

Liang G.H.L. and Liang Y.T.S. (1972). Effects of atrazine on chromosomal behavior in sorghum. Can. J. Genet. Cytol. 14 (2), 423-427. DOI: 10.1139/g72-053

Lindsley D.L. and Zimm G.G. (1992). The genome of Drosophila melanogaster. Academic Press, San Diego, California, USA, 1133 pp.

Mervosh T.L., Sims G.K. and Stoller E.W. (1995). Clomazone fate in soil as affected by microbial activity, temperature, and soil moisture. J. Agric. Food Chem. 43 (2), 537-543. DOI: 10.1021/jf00050a052

Navarro S., Vela N., García C. and Navarro G. (2003). Persistence of simazine and terbuthylazine in a semiarid soil after organic amendment with urban sewage sludge. J. Agric. Food Chem. 51 (25), 7359-7365. DOI: $10.1021 / \mathrm{jf034435s}$

Nebert D.W., Wikvall K. and Miller W.L. (2013). Human cytochromes P450 in health and disease. Phil. Trans. R. Soc. B. 368 (1612), 20120431. DOI: $10.1098 /$ rstb.2012.0431

O’Connor J.C., Plowchalk D.R., Van Pelt C.S., Davis L.G. and Cook J.C. (2000). Role of prolactin in chloro-Striazine rat mammary tumorigenesis. Drug. Chem. Toxicol. 23 (4), 575-601. DOI: $10.1081 /$ DCT-100101972

Papapaulou P. (2001). Linuron cytogenetic activity on human lymphocytes treated in vitro. Evaluation of clastogenic and aneugenic potential using cytokinesis block micronucleus assay in combination with fluorescence in situ hybridization (FISH) Fresen. Environ. Bull. 10 (5), 431-437.

Park S., Kim S., Jin H., Lee K. and Bae J. (2014). Impaired development of female mouse offspring maternally exposed to simazine. Environ. Toxicol. Pharmacol. 38 (3), 845-851. DOI: 10.1016/j.etap.2014.10.008

Pascal-Lorber S., Alsayeda H., Jouanin I., Debrauwer L., Canlet C. and Laurent F. (2010). Metabolic fate of $\left[{ }^{14} \mathrm{C}\right]$ diuron and $\left[{ }^{14} \mathrm{C}\right]$ linuron in wheat (Triticum aestivum) and radish (Raphanus sativus). J. Agric. Food Chem. 58 (20), 10935-10944. DOI: 10.1021/jf101937x

Patussi C. and Bündchen M. (2013). In situ genotoxicity evaluation of triazines using Tradescantia clone 4430 Trad-SHM bioassay. Ciênc. Saúde Coletiva 18 (4), 1173-1178. DOI: 10.1590/S1413-81232013000400030

Peraza-Vega R.I., Castañeda-Sortibrán A.N., Valverde M., Rojas E. and Rodríguez-Arnaiz R. (2016). Assessing genotoxicity of diuron on Drosophila melanogaster by the wing-spot test and the wing imaginal disk comet assay. Toxicol. Ind. Health 33 (5), 443-453. DOI: $0.1177 / 0748233716670536$

Plewa M.J., Wagner E.D., Gentile G.J. and Gentile J.M. (1984). An evaluation of the genotoxic properties 
of herbicides following plant and animal activation. Mutat. Res. 136 (3), 233-245.

DOI: $10.1016 / 0165-1218(84) 90057-0$

Plewa M.J. and Wagner E.D. (1993). Activation of promutagens by green plants. Ann. Rev. Genet. 27 (1), 93-113. DOI: 10.1146/annurev.ge.27.120193.000521

Rodríguez-Arnaiz R. (2003). Drosophila como organismo modelo en la Biología Experimental. In: Biología celular y molecular (Jiménez L.F. y Merchant H., Eds.) Editorial Pearson Educación de México, Mexico City, Mexico, 761-791.

Rodríguez-Arnaiz R., Ramos M.P., Gaytán O.J.C., Rodriguez Z.A. and Zimmering S. (1989). Genotoxicity of the herbicides dalapon and diuron in Drosophila melanogaster. Rev. Int. Contam. Ambie. 5 (1), 59-64.

Rodríguez-Arnaiz R., Vogel E.W. and Szakmary A. (1993). Strong intra-species variability in the metabolic conversion of six procarcinogens to somatic cell recombinagens in Drosophila. Mutagenesis 8 (6), 543-551. DOI: $10.1093 /$ mutage/8.6.543

Rodríguez-Arnaiz R., Castañeda S.A. and Ordaz T.G. (2006). Biotransformación de xenobióticos mediada por los citocromos P450 en Drosophila melanogaster. In: Tópicos de genética (Pimentel E., Ed.). Universidad Autónoma del Estado de México-Sociedad Mexicana de Genética, Estado de México, Mexico, 77-94.

Salvagni J., Ternus R.Z. and Fuentefria A.M. (2011). Assessment of the genotoxic impact of pesticides on farming communities in the countryside of Santa Catarina State, Brazil. Genet. Mol. Biol. 34 (1), 122-126. DOI: $10.1590 / \mathrm{S} 1415-47572010005000104$

Sanderson J.T. (2006). The steroid hormone biosynthesis pathway as a target for endocrine-disrupting chemicals. Toxicol. Sci. 94 (1), 3-21. DOI: 10.1093/toxsci/kfl051

Santi A., Menezes C., Duarte M.M., Leitemperger J., Lopes T. and Loro V.L. (2011). Oxidative stress biomarker and acetylcholinesterase activity in human erythrocytes exposed to clomazone (in vitro). Interdiscip. Toxicol. 4 (3), 149-153.

DOI: $10.2478 / v 10102-011-0023-9$
Santos S.M., Videira R.A., Fernandez M.A., Santos M.S., Moreno A.J., Vicente J. A. and Jurado A.S. (2014). Toxicity of the herbicide linuron as assessed by bacterial and mitochondrial model systems. Toxicol. in Vitro 28 (5), 932-939. DOI: 10.1016/j.tiv.2014.04.004 Scassellati-Sforzolini G., Pasquini R., Moretti M., Villarini M., Fatigoni C. Dolara P., Monarca S., Caderni G., Kuchenmeister F., Schmezer P. and Pool-Zobel B. (1997). In vivo studies on genotoxicity of pure and commercial linuron. Mutat. Res. 390 (3), 207-221. DOI: $10.1016 / \mathrm{S} 1383-5718(97) 00012-0$

Tennant A.H., Peng B. and Kligerman A.D. (2001). Genotoxicity studies of three triazine herbicides: In vivo studies using the alkaline single cell gel (SCG) assay. Mutat. Res. 493 (1), 1-10.

DOI: $10.1016 / \mathrm{S} 1383-5718(01) 00145-0$

Torres C., Ribas G., Xamena N., Creus A. and Marcos R. (1992). Genotoxicity of four herbicides in the Drosophila wing spot test. Mutat. Res. 280 (4), 291-295. DOI: 10.1016/0165-1218(92)90060-D

US EPA (1988). Pesticide fact handbook. Noisy data. United States Environmental Protection Agency. New York, USA, 484-490.

US EPA (2007). EPA-HQ-OPP-2006-0113. Clomazone summary document registration review: Initial docket. United States Environmental Protection Agency. Washington DC, USA, 9-28.

US EPA(2010). EPA-HQ-OPP-2010-0228-0013. Linuron summary document registration review: Initial docket. Form 8570-1. United States Environmental Protection Agency. Washington DC, USA, 2 pp.

Van Schaik N. and Graf U. (1993). Structure-activity relationships of tricyclic antidepressants and related compounds in the wing somatic mutation and recombination test of Drosophila melanogaster. Mutat. Res. Fund. Mol. Mech. Mutagen. 286 (2), 155-163. DOI: $10.1016 / 0027-5107(93) 90179-J$ 